
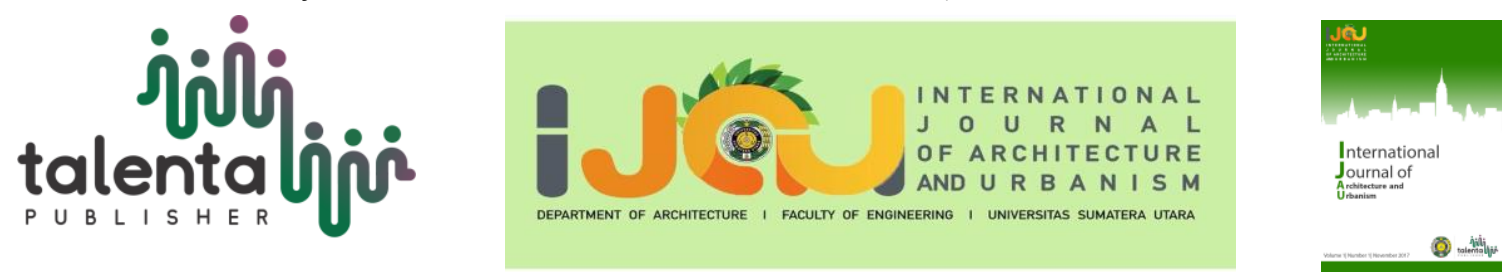

\title{
Sustainable Landscape Criteria in Design Concept of Taman Merah Kampung Pelangi, Malang City
}

\author{
Suryo Tri Harjanto', Hamka ${ }^{1}$ \\ ${ }^{1}$ Departement of Architecture, Faculty of Civil Engineering and Planning, Institut Teknologi Nasional, \\ Malang, Indonesia]
}

\begin{abstract}
Taman Merah is one of the thematic parks planned by the residents of Kampung Pelangi to provide a forum for activities and meet the needs of green open space for the environment by utilizing the empty land in Kampung Pelangi environment. This activity is a service program communities that aims to help residents plan and design the Red Park according to their needs. The method that used is the landscape architecture design method with a sustainable landscape approach, starting from site surveys, identifying people's needs and activities, studying literature related to sustainable landscape criteria to be applied to the Taman Merah design concept, compiling programming and design concepts. The results of the study obtained are the criteria for sustainable landscapes that are applied in the design concept including environmental, economic, socio-cultural, aesthetic, and institutional aspects. The five criteria were identified to be used as the basis for the Taman Merah design concept. The sustainability of these five aspects aims to improve the quality of the environment, improve the residents' economy, a forum for the actualization of sociocultural activities, provide interesting place experiences, and foster collaboration between residents and community groups in Kampung Pelangi RW 9 Joyogrand Housing, Merjosari Village, Malang City.
\end{abstract}

Keyword: sustainable lanscape, communal space, consept design

Received 8-3-2021 | Revised 15-3-2021 | Accepted 31-3-2021

\section{Introduction}

Taman Merah is of the thematic park concepts planned by the resident of Kampung Tematik Kampung pelangi, RW 09, Joyogrand Housing, Merjosari Village, Malang City. Kampung Pelangi is an urban village that carries the theme of diversity of resident's backgrounds that want to be manifested in colorful thematic parks in the form of taman merah, taman jingga, taman kuning, taman hijau, taman biru dan taman ungu. The names of each parks have a meaning, specifically for taman merah, signifying a center of activity or a communal space for residents to gather. The plans for these parks are a form of utilization of public facilities in the

\footnotetext{
*Corresponding author at: Departement of Architecture, Faculty of Civil Engineering and Planning, Institut Teknologi Nasional, Jl. Sigura-Gura No.2, Malang, Indonesia
} 
form of open spaces that have not been utilized properly. The use of the Taman Merah open space is an effort to provide a forum for activities for the residents of Kampung Pelangi, and also to meet the needs for environmental green open space in Kampung Pelangi area (Figure 1).

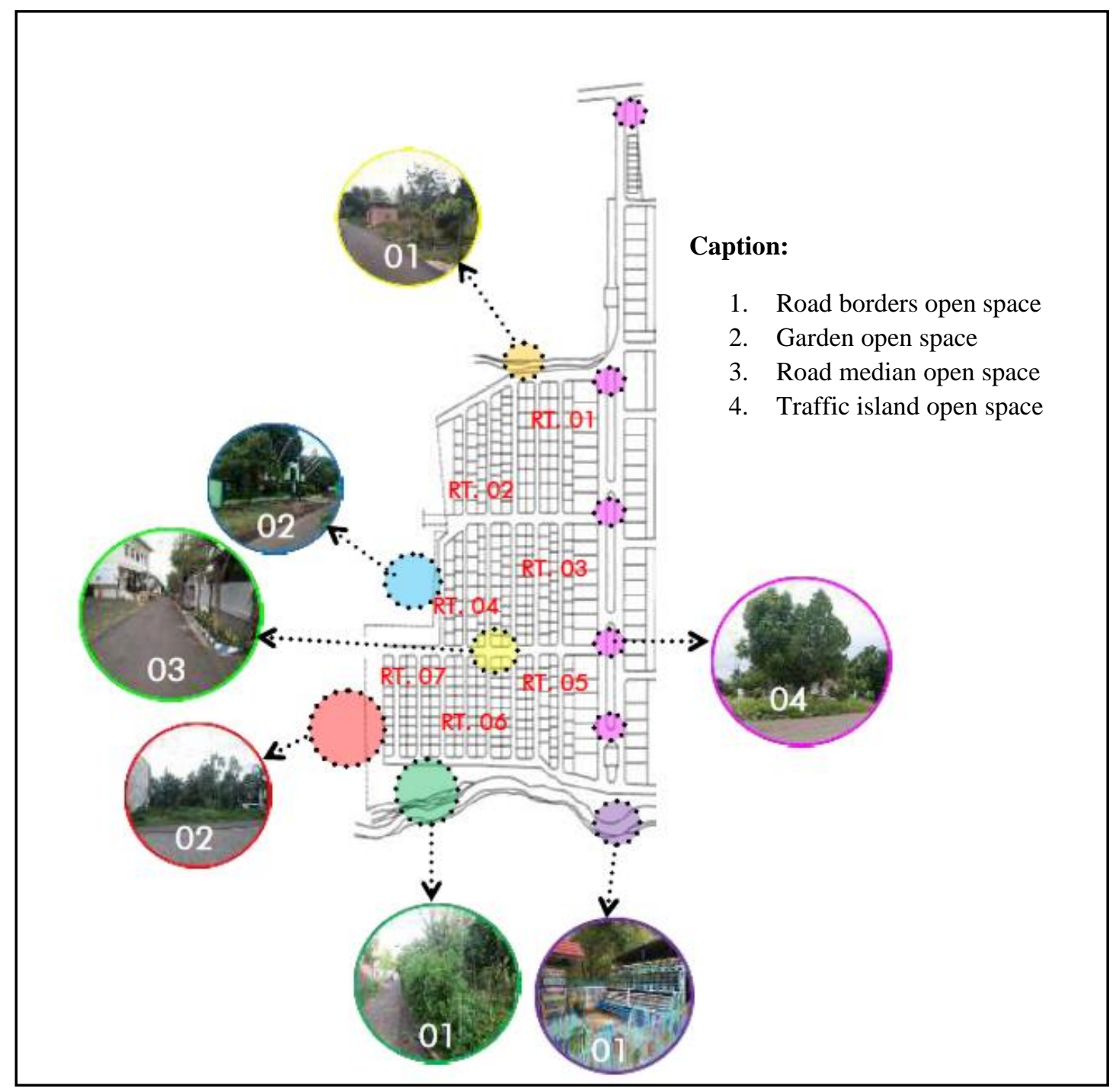

Figure 1. The location of Taman Merah and the distribution map of the Kampung Pelangi open space public facilities

Kampung Pelangi is a residential area located in RW 9 area of Merjosari Village, Lowokwaru District, Malang City. Its citizens come from an ethnic, religious and occupational backgrounds who are united in diversity. In 2016, the residents participated in Kampung Tematik Malang City competition which became the forerunner to the name Kampung Tematik. Kapung Tematik competition aims to create urban villages as new tourist destinations. The development towards tourism is expected to be able to improve the quality of life and economy of the residents, but still pay attention to the physical, social, and cultural conditions of the residents. In line with these objectives, we raise the topic of sustainable landscapes as the basis for the design concept of the Taman Merah. Thus aspects that affect the lives of citizens will continue to do well. 


\section{Literature Review}

Green open space

Constitution No.26 concerning Spatial Planning Article 17 Paragraph 5 of 2007 mandates that $30 \%$ of the city area is in the form of RTH, $20 \%$ is public RTH and $10 \%$ is private RTH [1]. The Government of Malang City has carried out several revitalizations of city parks, but the result has resulted in a reduction in the area of green open space, which is due to the increase in public facilities in the park area, so it is necessary to consider the use of pavement material [2]. Green Open Space according to Permen PU No. 5 of 2008, is land that is open, overgrown with plants naturally or on purpose [3], while according to Permendagri No. 1 of 2007 Regarding Urban Green Open Space Planning, that one type of green open space is a residential and residential area park which is intended for recreational needs for residents around housing and settlements, functions as the lungs of the city, visual beauty, interaction space, silencer noise, play areas, recreation areas, and to create a comfortable environment [4]. Arrangement of plants in green open spaces has ecological functions such as improving the quality of the environment, water, soil, preventing flooding, and minimizing air pollution. socio-cultural functions such as a space for social interaction, recreation areas, and regional landmark. architectural functions such as improving quality. visual and comfort area, and economic function to act as a means of urban green tourism so as to foster employment [5].

Sustainable landscape criteria

There are five pillars of sustainable landscapes such as ecological aspects (green space, water quality, air, flora and fauna), economic agriculture / cultivation and tourism, socio-culture (education, health, experience, local wisdom, participation and cultural identity), aesthetics aspecs (experience of space and place and visual quality), and political aspects related to policy [6]. Interpretations of urban sustainability are generally consistent with the six elements of the sustainability landscape such as environment, economy, equality, aesthetics, experience and ethics. Protecting ecosystems and human health, ensuring equal access to resources and services, maintaining culture and diversity and social integrity [7]. The main indicators of sustainable landscapes for the development of an area such as increase the physical quality of the landscape environment through the preservation and provision of new infrastructure, the economic dimension through increasing the number of visitors, entrepreneurship, investment and tourism, the socio-cultural dimension through developing relationships and network collaboration, and developing potential local [8].

If connecting the criteria for sustainable landscapes and green open space, it will find the compatibility of the goals and objectives between the two, so that these two things are used as the main reference in compiling the design concept of Taman Merah Kampung Pelangi design. Based on several previous research literature related to sustainable landscapes, the criteria for 
sustainable landscapes include environmental / ecological (environmental protection), economic (social economic equity), socio-cultural (community livability), aesthetic / architectural (visual quality), and institutional (good policy) (Figure 2).

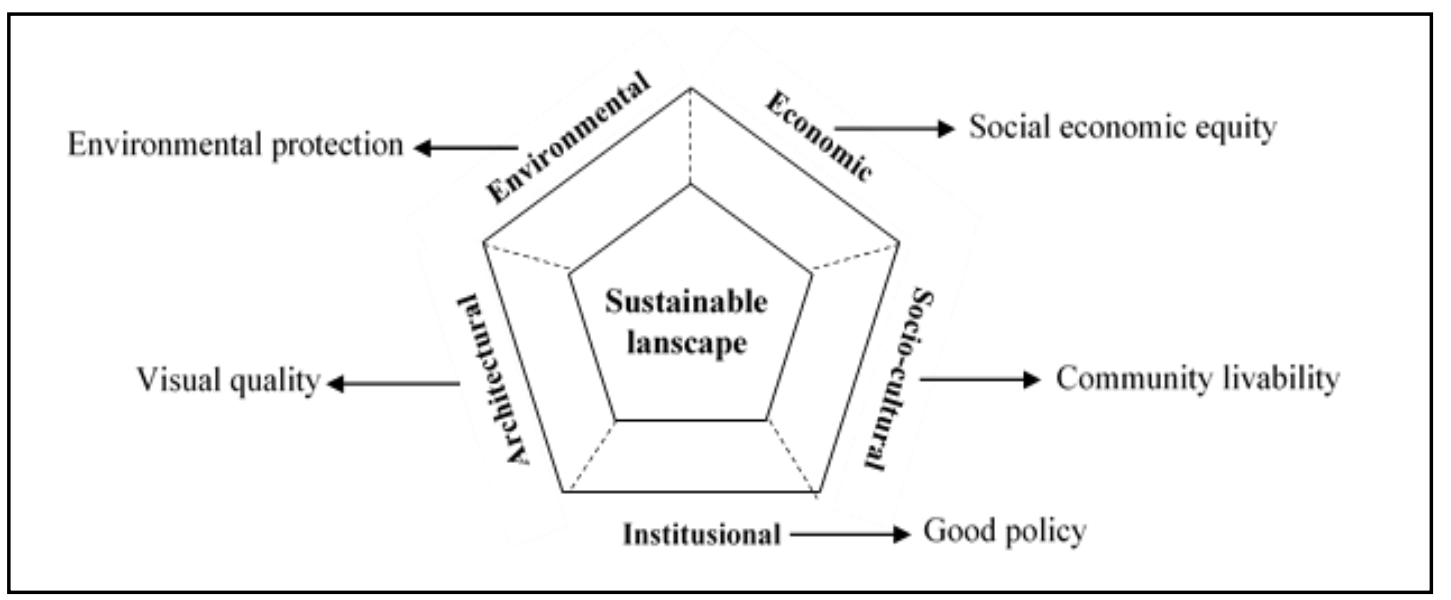

Figure 2. Criteria of sustainable landscape

The description of the sustainable landscape criteria indicators can be seen in the following table (Table 1):

Table 1. Indicator of Sustainable Landscape

\section{Criteria of Indicator \\ Sustainable \\ Landscape}

\begin{tabular}{ll}
\hline Environmental & $\begin{array}{l}\text { Availability of green open spaces, maintaining water and air quality, } \\
\text { flora and fauna, productive land use, determining land use functions, } \\
\text { using environmentally friendly materials, saving energy }\end{array}$ \\
\hline Economic & $\begin{array}{l}\text { Agricultural and livestock cultivation, tourism development, } \\
\text { entrepreneurship / investment / employment }\end{array}$ \\
\hline Social-culture & $\begin{array}{l}\text { Education, health, scientific experience, cultural identity / local wisdom, } \\
\text { spaces for social interaction, group or individual collaboration }\end{array}$ \\
\hline Architectural & $\begin{array}{l}\text { Provides a space and place experience of an attractive visual quality and } \\
\text { a comfortable environment }\end{array}$ \\
\hline Institutional & Policy, participation and commitment of all parties \\
\hline
\end{tabular}

Architectural design concepts and approaches

The Concepts of thecontext of architecture are the main ideas, plans, thoughts, or ideas that guide the designer or architect in realizing the desired design. The architectural concept is not a theoretical formation, but a comprehensive understanding of specific design problems resulting from the thought process to project a suitable architectural form based on basic data such as users, site data, and design references [9]. Conceptuals are used to describe design elements such as the site, organization of space, use of function, form, scale, and the style and experience 
envisioned. [10]. The concept of design / design according to the Indonesian Architects Association is the basis of thought and considerations from all aspects that underlie the realization of design ideas that accommodate the needs, objectives and constraints of a project, so there needs to be clarity of data and information from users / clients related to requirements and the need so that the goals and objectives are properly achieved [11].

The design approach used to complete this activity is to use the principle approach of landscape architecture, because this landscape architecture is the most appropriate to the context of green open space and the sustainable landscape itself. Landscape architecture has 4 principles of study and practice, such as; first as a three-dimensional construction that describes the visuals of open space, surfaces, organization, and arrangement. Second, as history that expresses the character of the location, not only in terms of geography, but also history, socio-culture, and aesthetics. Third, as a scale continuum in the form of a relational structure that connects scales, spatial, ecological, functional and social entities. Fourth, as a process, namely, holistic and dynamic system [12].

The role of landscape architecture in urban areas is to organize open spaces so that they are compatible with the visual environment, forming, and fostering the human character within it. The role of landscape architects helping to solve urban problems must be based on the sociocultural aspects of the landscape, such as understanding and transforming the community's culture in the use of open space into current open space needs, estimating future needs, without losing the old character. Ecological aspects of the environment, such as providing alternative input related to open space planning, basic understanding of climate, and protecting the diversity of ecosystems that exist in the environment. Landscape engineering aspects are mastery of landscape lighting, mechanical, electrical, aquascape (water landscape), hardscape (pavement), softscape (plants / vegetation) [13].

\section{Methods}

The method used is the landscape architecture design method with a sustainable landscape criteria approach, starting from site surveys, identifying people's needs and activities, studying literature related to sustainable landscape criteria to be applied to Taman Merah design concept, compiling programming and design concepts, in the form of ideas. The design is implemented in the arrangement of Taman Merah softscape and hardscape elements. The process of drafting the design concept considers the criteria for sustainable landscapes which include environmental, economic, socio-cultural, aesthetic, and institutional aspects. The five criteria were identified through field observations to be used as the basis for the design concept of Taman Merah Kampung Pelangi RW 9 Joyogrand Housing, Merjosari Village, Malang City. 


\section{$4 \quad$ Result and Analysis}

Identification criteria for sustainable landscapes

Based on the results of the field identification and the results of the interview with the head of RW 9, the following are the environmental conditions for the residents of Kampung Pelangi based on five criteria for sustainable landscapes: Table 2:

Table 2. Results of field identification for sustainable landscape indicators

\section{Criteria of Indicator \\ Sustainable \\ Landscape}

Environmental Availability of green open spaces, maintaining water and air quality, flora and fauna, productive land use, determining land use functions, using environmentally friendly materials, saving energy

\section{Identification results}

-There is a potential for public facilities in the form of empty land that can be used as green open space, one of it is Taman Merah which is being designed

-At the site location there are existing trees that need to be maintained to maintain air quality and as a place for wild fauna

-The site location has not been used as productive land, so it is necessary to plant productive plants within the site

-There needs to be an arrangement of land use functions based on existing activities

Economic Agricultural and livestock cultivation, tourism development, entrepreneurship / investment / employment

\section{Idntification results}

-There are several independent community businesses such as passion fruit syrup products, and snacks that need to be accommodated in Taman Merah, including several street vendors who travel around the neighborhood

-Some of the residents cultivate their own land and in some empty land areas, so that these activities need to be accommodated in Taman Merah which can later be managed jointly by residents

-The concept of Taman Merah needs to be made with good visual quality, so that the Taman Merah can be developed as a green open space tourism that drive the economic activities of residents

Social-culture Education, health, scientific experience, cultural identity / local wisdom, spaces for social interaction, group or individual collaboration 


\section{Identificaton Results}

-Kampung Pelangi residents consist of various age groups, so it is necessary to accommodate activities based on age groups, ranging from children, adolescents, adults, to the elderly

-There is early childhood education POS PAUD Cempaka

-Religious education, weekly and monthly routine recitation activities

-There is an empowerment group for the welfare of families and mothers (PKK)

-In terms of health, there are sports activities, posyandu for the elderly, and healthy gymnastics that are routinely carried out in front of a multipurpose building or in an open field

-There are art activities in the form of traditional music and dances by Singosongo Youth Organization as cultural identity and local wisdom

-In terms of environmental concern, there also a group of environmental cadres who focus on environmental concern

Architectural Provides a space and place experience of an attractive visual quality and a comfortable environment

\section{Identification results}

Visually, this Pelangi Village does not yet have an attractive visual character, so it needs to improve the visual quality of the existing ones, or by making spaces, places, or architectural markers that have character and represent the character of the residents and Kampung Pelangi itself. In the context of the Taman Merah, area markers and photo spots can be made that are attractive to visitors

Institutional Policy, participation and commitment of all parties

\section{Identification results}

Kampung Pelangi has a community groups that are under the government or formed based on the agreement of the residents, which is a big potential if its activities are accommodated in the design of Taman Merah. Considering the group's activities as one of the basic zoning functions of the park will help move sustainability away from the concept of sustainable landscapes itself.

\section{Existing site}

The location of the Taman Merah Kampung Pelangi site is in the neighborhood of Joyogrand RW 9, Merjosari Village, Malang City. The existing site is one of the public open space facilities owned by the housing, but so far it has not been utilized and managed properly. The location is adjacent to Uniga Housing on the west side, residents' houses on the east side, the river on the south side and residents on the north side. The location of the site is also close to 
Al-Ikhlas Mosque and the Multipurpose Building on the north side. The following is an overview of the existing conditions of the Taman Merah site, Figures 3 and 4.
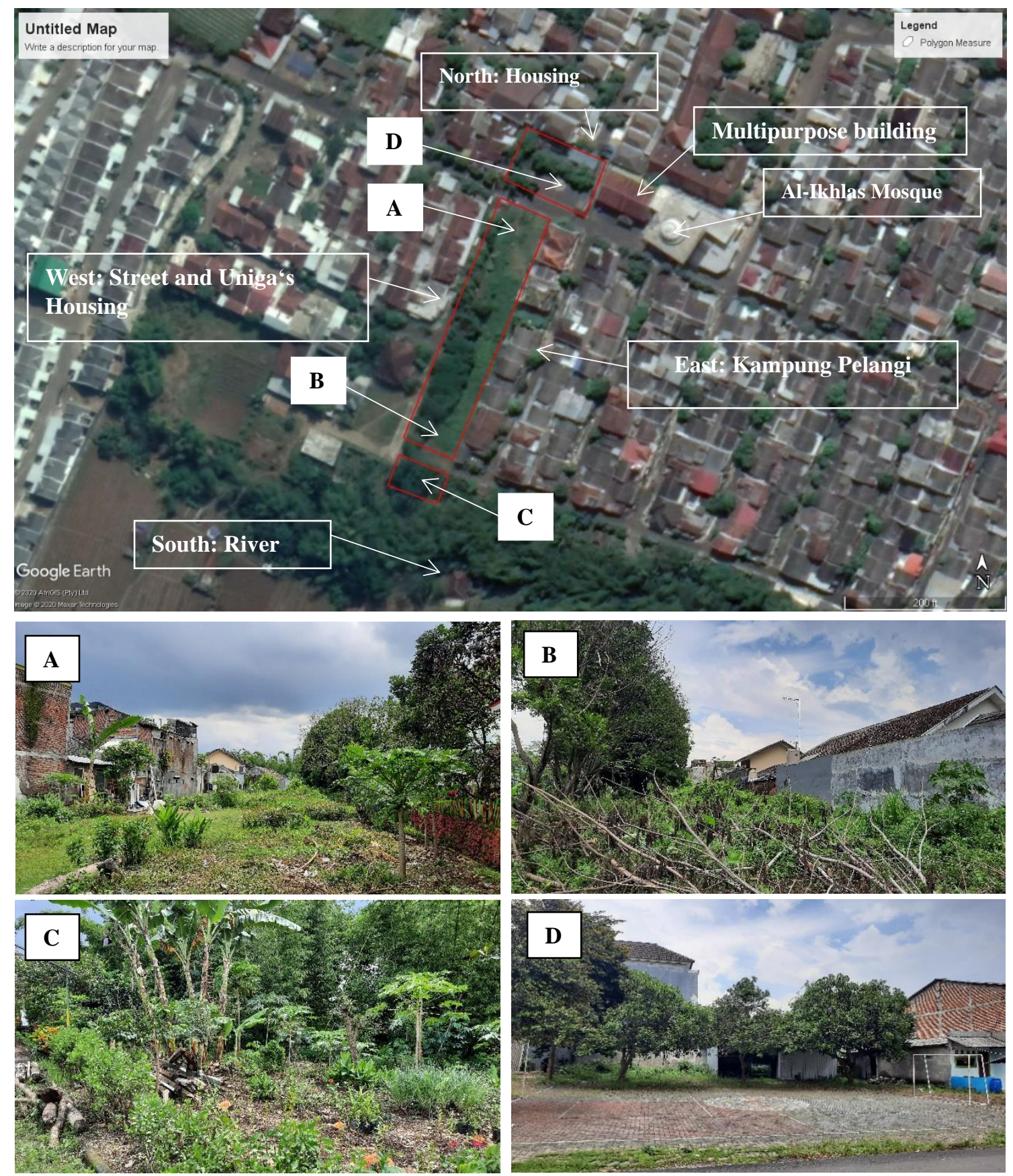

Figure 3. An overview of the existing site conditions

Figure $\mathrm{A}$ is the north side of the land in the center which is projected as the main entrance area of the park, and Figure B is the site condition in the south. The contours of the site are relatively flat and empty without vegetation in the middle of the land. It needs processing on the east side of the border which is directly adjacent to the walls of the residents' houses to make it look more attractive, through visual improvements to the walls or covering them with shady trees. Figure $\mathrm{C}$ is an area of south side land, where some residents plant medicinal plants or cooking spices, as well as fruits such as bananas and papayas. This area can be developed as a zone for productive 
plant cultivation. Figure $\mathrm{D}$ is the area of land on the north side. This area is used by residents as a children's play area and a sports field. This area can be used as a parking area for vehicles, by moving the play area to the central land area. The land area is quite large, so it is necessary to divide land zoning according to the needs and activities of residents.

Programing

This programming stage is a stage to determine park facilities based on users and types of activities by considering sustainable landscape criteria. The following are park facilities, users and types of activities accommodated in Taman Merah, Table 3:

Table 3. The facilities of Taman Merah

\begin{tabular}{llll}
\hline User / citizen group & Activities & Facilities required & \\
\hline POS PAUD Cempaka & $\begin{array}{l}\text { Playing and studying for } \\
\text { childhood education }\end{array}$ & $\begin{array}{l}\text { Playground area and early } \\
\text { childhood education }\end{array}$ \\
\hline $\begin{array}{l}\text { Fairy tales and reading } \\
\text { group }\end{array}$ & $\begin{array}{l}\text { Reading and listening to a fairy } \\
\text { tales }\end{array}$ & Library \\
\hline PKK, RW, RT group & Meeting, sosialization, discuss & Pendopo and Open Garden \\
\hline Waqiah Indonesia & $\begin{array}{l}\text { Religious activities once a } \\
\text { month }\end{array}$ & Pendopo / field / open area \\
\hline $\begin{array}{l}\text { Karang Taruna } \\
\text { 'Singosongo" }\end{array}$ & Dancing and Music & Stage art \\
\hline $\begin{array}{l}\text { Eldery group } \\
\text { (Karangwreda) }\end{array}$ & - Medical check up & $\begin{array}{l}\text {-Health post } \\
\text { - Elderly gym }\end{array}$ & -Gymnastics Field \\
& -Reflexology & - Reflexology Park & \\
\hline Kader lingkungan & $\begin{array}{l}\text { Take care of the environment, } \\
\text { grow crops }\end{array}$ & $\begin{array}{l}\text { Plant cultivation area } \\
\text { cultivation garden }\end{array}$
\end{tabular}

\begin{tabular}{lll}
\hline $\begin{array}{l}\text { Children, teenagers, } \\
\text { adults }\end{array}$ & Exercising & $\begin{array}{l}\text { A multi-functional field for } \\
\text { sports (volleyball and futsal) }\end{array}$ \\
\hline $\begin{array}{l}\text { Business Community } \\
\text { and street vendors }\end{array}$ & Selling some product or foods & Selling areas and selling stalls \\
\hline
\end{tabular}

\begin{tabular}{lll}
\hline Visitors & -Visiting by vehicle & -Vehicle parking area \\
& - Travel and relax destination & -Photo spot and relax \\
& - Sports & -Sports facilities \\
\hline All of residents & Cleaning & Toilet \\
\hline Securities & $\begin{array}{l}\text { Maintain the park environment, } \\
\text { patrol, arrange parking }\end{array}$ & Guardhouse \\
\hline
\end{tabular}


Based on the needs of Taman Merah facility, the following is a description of the design criteria and their relationship to the criteria for sustainable landscapes, Table 4:

Table 4. Design Criteria for Taman Merah facilities

\begin{tabular}{|c|c|c|c|c|c|}
\hline \multirow[t]{2}{*}{ Facilities } & \multirow[t]{2}{*}{ Design Criteria } & \multicolumn{4}{|c|}{$\begin{array}{l}\text { Sustainable } \\
\text { landscape } \\
\text { criteria }\end{array}$} \\
\hline & & 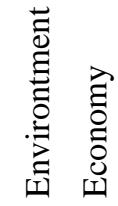 & 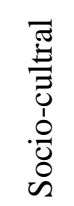 & 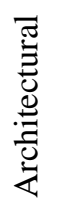 & 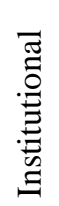 \\
\hline
\end{tabular}

\begin{tabular}{ll}
\hline Playground & $\begin{array}{l}\text { Serves as a forum for shaping the educational character of } \\
\text { area and } \\
\text { children in Kampung Pelangi }\end{array}$ \\
early & \\
childhood \\
education
\end{tabular}

-Provide play facilities for children

-Provide a closed learning area / place

-Provides an element of education

Library Serves as a place to add insight and knowledge to the children

In the form of a closed library (integrated with the early childhood education area) to store a collection of reading books and open in the form of a reading garden and fairy tale performances

Space / place quality:

Shady atmosphere under the tree (addition of trees), with an attractive design for children

Materials: combine with recycled materials and use bright colors

Zone Playground areas and early childhood education and libraries are located in the education zone

Pendopo Serves as an area for community meetings or discussions and Open that can be used jointly and alternately between groups of Area citizens as a form of social interaction and collaboration between group institutions

The pavilion is a roofed space, while the garden is open under a tree and provided with tables and benches

Plaza/ Serves as a multifunctional common space that can be Open Area used by all residents for activities as a means of social interaction and health (elderly exercise)

-Is a large open space area without trees, the material uses a combination of pavement and grass to reduce the effect 
of heat and still provide water catchment areas

-There is an area marker sklupture that symbolizes Taman Merah and the character of the residents of Kampung Pelangi

Stage Art Serves as an area for performing arts activities and religious activities as a means of developing and promoting the value of local wisdom

The stage is roofed and open, connected to a higher level with an open plaza

Elderly It functions as a facility for the elderly in checking their group health, and light exercise through exercise and facilities reflexology. Especially for the elderly gymnastics area, they are combined in the plaza

-Health Post is made closed with an area that suits the needs

-Reflexology park in the form of a walking path made of gravel equipped with a handrail and placed on the outside of the garden

\begin{tabular}{|c|c|}
\hline Zone & $\begin{array}{l}\text { The area of the pavilion, plaza, stage, and facilities for the } \\
\text { elderly are placed in a common / common function zoning } \\
\text { group }\end{array}$ \\
\hline
\end{tabular}

Plant Created to support people's economy and as a form of selfcultivation sufficiency and food security, residents can manage the area benefit from the results together. It can also be processed as a food or beverage product for sale in the economic area of residents. Cultivation gardens can also be used as educational tours for the cultivation of productive plants and livestock that can support tourism development in Kampung Pelangi. In addition, these plants can also help improve environmental quality

There needs to be a grouping of plant types and layout of cultivation areas that have good aesthetics, so that, visitors can experience interesting places. It is necessary to provide a water storage pool from both rivers and rainwater. The cultivation area is placed in the cultivation zone

Multi- $\quad$ Serving as a means of social interaction and citizen health, functional as well as a tourist attraction, the field is multifunctional field for which can be used interchangeably for volleyball and sports futsal.

(volleyball and futsal)

Consider not using pavement material, an alternative to white sand material so that, it can function as an infiltration area. This field is placed in a sports zone and around the field is a spectator area 


\begin{tabular}{|c|c|c|}
\hline \multirow[t]{2}{*}{$\begin{array}{l}\text { selling } \\
\text { stalls }\end{array}$} & $\begin{array}{l}\text { beverage needs in the park area, this area is placed as an } \\
\text { economic zoning function }\end{array}$ & $\checkmark \checkmark \checkmark$ \\
\hline & $\begin{array}{l}\text { Set up closed stalls for community business groups and } \\
\text { open areas for street vendors }\end{array}$ & \\
\hline $\begin{array}{l}\text { Supporting } \\
\text { facilities }\end{array}$ & Consists of a parking area, guardhouse and toilets & $\checkmark$ \\
\hline
\end{tabular}

The use of landscape materials mostly uses softscape elements such as grass, white sand, and coral and reduces the use of hardscape, especially pavement to minimize the reduction in water infiltration areas. The park does not use water elements such as fountains in order to reduce the use of electrical power. Only provided a rainwater storage pond for the needs of plant cultivation and fish farming. The types of plants planted in the Taman Merah area are divided into two, namely, types of shade plants for ecological functions (improving air quality and as a place for wild fauna), and types of productive plants such as fruits, vegetables and medicines which also serve as an ecological function (improving quality of land) as well as the economic function of residents.

Site zoning concept

Based on the Taman Merah facilities, site zoning is divided into 6 main zoning, namely, economic zoning, supporting zoning, general zoning, educational zoning, sports zoning, and cultivation zoning, the following is an overview of the distribution of zoning on the Taman Merah site, Figure 4:

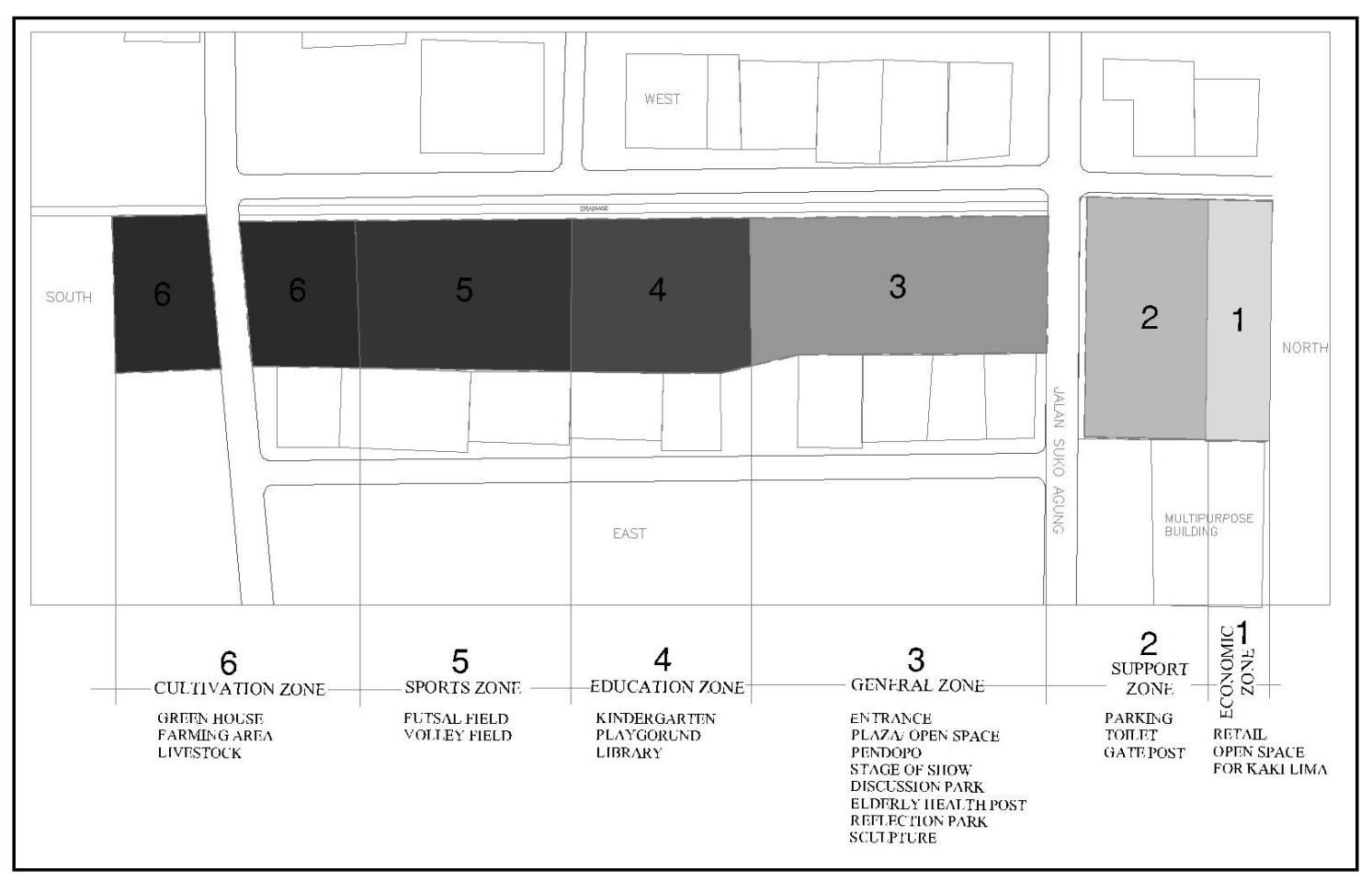

Figure 4. Site zoning concept of Taman Merah 
The concept of facility layout, circulation and vegetation

The facility layout concept is arranged based on the zoning function group area of the site (Figure 4) and then developed as shown in Figure 5. Pedestrian circulation is made around the park on the east, west and center as a link so that each zoning can be connected to one another. The concept of vegetation follows pedestrians on the east and west sides. Some of the existing tree vegetation in the west is preserved and then added to the north following the circulation path. On the east side, shade trees are also added for the function of shading to follow the circulation path, Figure 5.

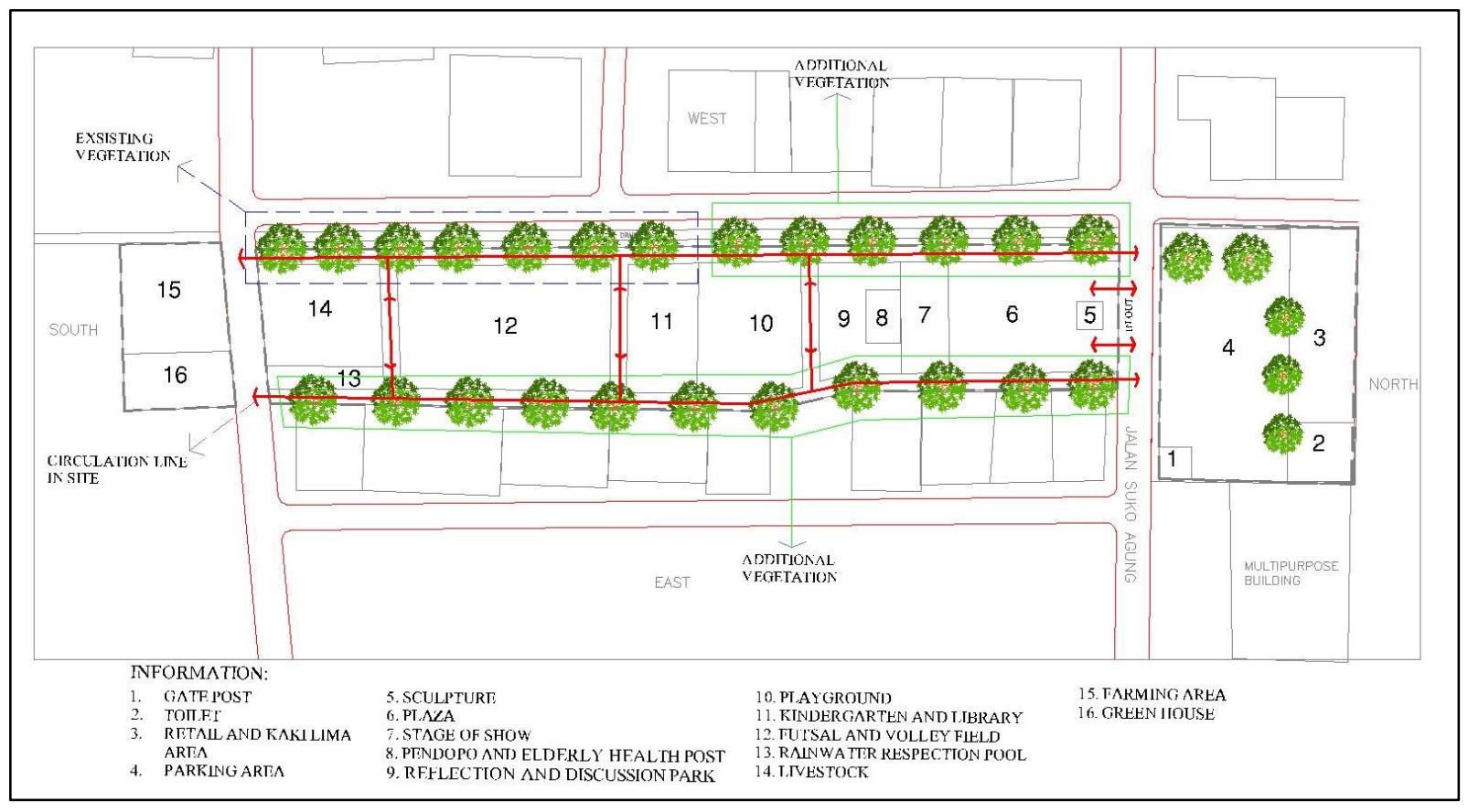

Figure 5. Concept of facility layout, circulation and vegetation

\section{Conclusion}

The application of sustainable landscape criteria in the concept design of Taman Merah Kampung Pelangi aims to provide sustainability benefits for Kampung Pelangi residents from five aspects of sustainable landscapes, namely, (1). environmental aspects so that the quality of the environment and the ecosystem can be maintained properly, (2). The economic aspect so that the economic capacity of the citizens can increase, can be realized through planting productive plants as a form of food independence and security, the results of it can also be processed to become a product of people's businesses. In addition, by designing the park for green open roaring tourism designation, and then to attract visitors to Kampung Pelangi environment. (3). Socio-cultural aspects in order to increase knowledge and insight, maintain the health of citizens, a means of citizen interaction, and maintain the heritage of local wisdom through arts. (4). Architectural aspects are needed to provide an interesting space and place experience for residents and visitors to be comfortable doing activities in this Taman Merah. (5). 
Institutional aspects are also very much needed through participation and cooperation between individuals, groups and institutions in making policies to realize the concept of sustainability in Taman Merah, Kampung Pelangi, Joyogrand Housing, RW 9 Kelurahan Merjosari, Malang City.

\section{REFERENCES}

[1] Undang-Undang No.26 tentang Penataan Ruang Pasal 17 Ayat 5 Tahun 2007

[2] Wikantiyoso, \& Tutuko. "Kajian Persentase Ruang Terbuka Hijau pada Implementasi Revitalisasi Taman Kota Malang”. LOCAL WISDOM, 11 (1), 16-41. 2019.

[3] Peraturan Menteri Pekerjaan Umum No. 5 Tahun 2008. Tentang Pedoman Penyediaan dan pemanfaatan Ruang Terbuka Hijau

[4] Permendagri No. 1 Tentang Penataan Ruang Terbuka Hijau Kawasan Perkotaan. Tahun 2007.

[5] Sulistyanto. "Penataan Ruang Terbuka Hijau (RTH) Pada Kawasan Rumah Pemotongan Hewan (Rph) Samarinda Sebagai Upaya Terciptanya Kawasan Hijau Pada Koridor Bandara Sei Siring Samarinda”. Jurnal Teknik Sipil dan Arsitektur. Universitas Tunas Pembangunan Surakarta. Vol 15, No 19. 2014.

[6] Çiftçioğlu and Sözen. "Towards Sustainable Landscape Development Indicators For North Cyprus". TÜBAV Bilim 10 (1) 2. 75-85. 2017.

[7] Messeidy. "Towards Accomplishment Of Urban Sustainability: Multifunctional Sustainable Landscapes". International Journal of Management and Applied Science Volume-3, Issue-12. 2017.

[8] Simsek. Examining the Role of Cultural Landscape in Regional Development: Defining Criteria and Looking at Ephesus. ICONARP, International Journal of Architecture \& Planning. Volume 5, Issue 1, pp: 42-65. 2017.

[9] Ashadi. “Konsep Desain Arsitektur”. Arsitektur UMJ Press: Jakarta Pusat. 2019.

[10] Steier, Rolf; Pierroux, Palmyre. "What is 'the Concept'?' Sites of Conceptual Formation in a TouringArchitecture Workshop", Nordic Journal of Digital Lileracy, Vol 6, 2011, NR 03, 138-156. 2011.

[11] Ikatan Arsitek Indonesia Jakarta. Lingkup Pekerjaan Arsitek. [Online]. Available: https://iai-jakarta.org/informasi/lingkup-pekerjaan-arsitek. [Accessed: Dec, 31, 2020].

[12] Nijhuis, Steffen. Flowscapesexploring Landscape Infrastructures. Francisco de Vitoria University: Spain. 55-58. 2013.

[13] Hakim, Rustam. Komponen Perancangan Arsitektur Lanskap, Prinsip-Unsur dan Aplikasi Desain. Bumi Aksara: Jakarta. 2012. 